\title{
PENGARUH ARUS KAS OPERASI, ARUS KAS INVESTASI, ARUS KAS PENDANAAN DAN LABA AKUNTANSI TERHADAP RETURN SAHAM PASAR EMITEN SUB SEKTOR MAKANAN DAN MINUMAN
}

\author{
Budi Setyawan \\ Fakultas Ekonomi Universitas Pamulang \\ Email: dosen01453@unpam.ac.id
}

\begin{abstract}
Abstrak
Penelitian ini bertujuan untuk menganalisis pengaruh arus kas operasi, arus kas investasi, arus kas pendanaan dan laba akuntansi terhadap return saham pada emiten sub sektor makanan dan minuman yang telah terdaftar di Bursa Efek Indonesia. Penelitian ini menggunakan sampel 12 emiten yang memenuhi kriteria peneliti, data yang digunakan adalah tahun 2015-2018. Pengolahan data menggunakan regresi berganda dengan SPSS 23.00. Hasil penelitian menunjukkan secara parsial hanya variabel arus kas pendanaan yang berpengaruh signifikan terhadap return saham, sedangkan variabel arus kas operasi, arus kas investasi dan laba akuntansi tidak berpengaruh terhadap return saham. secara simultan, terdapat pengaruh yang signifikan variabel bebas arus kas operasi, arus kas investasi, arus kas pendanaan dan laba akuntansi secara bersama-sama terhadap variabel terikat return saham.
\end{abstract}

Kata Kunci: Arus Kas Operasi, Arus Kas Investasi, Arus Kas Pendanaan, Laba Akuntansi, Return Saham.

\begin{abstract}
This study aims to analyze the effect of operating cash flow, investment This study aims to analyze the effect of operating cash flow, investment cash flow, funding cash flow and accounting profit on stock returns on listed food and beverage sub-sector listed on the Indonesia Stock Exchange. This study uses a sample of 12 issuers that meet the criteria of researchers, the data used are the years 2015-2018. Data processing using multiple regression with SPSS 23.00. The results showed partially only funding cash flow variables that had a significant effect on stock returns, while operating cash flow variables, investment cash flows and accounting profits had no effect on stock returns. Simultaneously, there is a significant influence of the independent variable operating cash flow, investment cash flow, funding cash flow and accounting profit together on the stock return dependent variable.
\end{abstract}

Keywords: Operation cash flow, Infestation Cash flow, Funding Cash Flow, Accounting Profit, Stock return

\section{PENDAHULUAN}

Pembiayaan merupakan salah satu fungsi perusahaan yang penting bagi keberhasilan usaha suatu perusahaan. Fungsi ini penting karena fungsi inilah yang melakukan usaha untuk mendapatkan dana. Baik perusahaan besar maupun kecil membutuhkan dana untuk menjalankan kegiatan usahanya. Dana yang dibutuhkan bisa diperoleh baik melalui pembiayaan dari dalam perusahaan (internal financing) maupun pembiayaan dari luar perusahaan (external financing). Sumber pembiayaan modal internal adalah berupa pemanfaatan laba yang tidak dibagikan sebagai dividen. Sumber pembiayaan eksternal diperoleh perusahaan dengan melakukan pinjaman kepada pihak lain atau menjual sahamnya kepada masyarakat (go public) di pasar modal.

Pasar modal merupakan pertemuan antara pihak yang memiliki kelebihan dana dengan pihak yang membutuhkan dana dengan cara memperjualbelikan sekuritas. Dengan demikian, pasar modal juga bisa diartikan sebagai pasar untuk memperjualbelikan sekuritas yang umumnya memiliki umur lebih dari satu tahun, seperti saham dan obligasi. (Tandelilin, 2010). Salah satu fungsi dari pasar modal adalah sarana untuk memobilisasi dana yang bersumber dari masyarakat ke berbagai sektor yang melaksanakan investasi. Dari dana tersebut dapat diubah menjadi faktor-faktor produksi mulai dari bahan baku, tenaga kerja, prasarana fisik dan teknologi sampai keahlian 
manajemen. Faktor-faktor tersebut terintegrasi dalam proses produksi yang akan memberikan nilai tambah bagi perusahaan.

Investor selalu ingin merasa aman saat menanamkan dana di pasar modal. Tujuan investor menanamkan dana di pasar modal adalah untuk memperoleh return (tingkat pengembalian) yang optimal diiringi dengan tingkat risiko yang minimal. Return atas kepemilikan sekuritas khususnya saham dapat diperoleh dalam dua bentuk, yaitu dividen dan capital gain (keuntungan yang diperoleh dari kenaikan harga saham). Harapan investor terhadap return positif dari dana yang diinvestasikan menjadi salah satu tantangan yang akan dihadapi oleh manajer investasi.

Return yang diterima oleh pemegang saham adalah pengembalian yang diterima atas investasi yang telah dilakukan. Return tersebut berupa 1). Capital gain yaitu keuntungan yang diperoleh dari selisih lebih pergerakan harga saham pada saat membeli dan menjual. 2). Keuntungan yang diperoleh dari pembagian dividen (Pradhono \& Christiawan, 2004). Dividen adalah laba yang dibagikan kepada para pemegang saham, agar investor dapat memperoleh return yang maksimal maka investor dalam mengambil keputusan untuk melakukan investasi di suatu perusahaan perlu mengetahui historis perusahaan dan menilai prospek perusahaan melalui laporan keuangan (Pradhono \& Christiawan, 2004).

Return saham merupakan pembayaran yang diterima karena hak kepemilikannya, ditambah dengan perubahan dalam harga pasar yang dibagi dengan harga awal (Horne, 2012). Return atau tingkat pengembalian adalah selisih antara jumlah yang diterima dengan jumlah yang diinvestasikan (Brigham, 2006). Return merupakan hasil yang diperoleh dari investasi. return dapat berupa return realisasi (Realized Return) atau return ekspektasian (Expected Return). Return realisasi merupakan return yang telah terjadi yang dihitung berdasarkan data historis. Return realisasi sangat penting karena dapat digunakan sebagai salah satu pengukur kinerja perusahaan. return ekspektasian adalah return yang diharapkan akan diperoleh investor dimasa mendatang, jadi return ekspektasian sifatnya belum terjadi (Jogiyanto, 2014).

Laporan keuangan merupakan hal yang penting pada dunia pasar modal, laporan keuangan adalah suatu informasi yang menggambarkan kondisi keuangan suatu perusahaan, dan lebih jauh informasi tersebut dapat dijadikan sebagai gambaran kinerja keuangan perusahaan tersebut (Fahmi, 2011). Suatu informasi akan memiliki makna atau nilai yang dianggap informatif bagi investor jika keberadaan informasi tersebut mampu mengubah kepercayaan para pengambil keputusan. Istilah tentang pasar efisien dapat diartikan secara berbeda untuk tujuan yang berbeda pula. Namun dalam bidang keuangan, konsep ini didefinisikan pada aspek informasi. Pasar yang efisien adalah pasar di mana harga semua sekuritas yang diperdagangkan telah mencerminkan semua informasi yang tersedia dan dapat diperoleh secara terbuka dan cepat (Fahmi, 2011). Salah satu informasi penting untuk menilai perusahaan adalah laporan keuangan. Laporan keuangan merupakan salah satu sumber utama informasi posisi keuangan, kinerja, dan arus kas perusahaan yang sangat penting bagi sejumlah pemakai dalam pengambilan keputusan ekonomi. Keputusan yang berdasarkan laporan keuangan dapat berupa keputusan investasi, pemberian pinjaman, maupun manajemen dalam pengelolaan perusahaan untuk meningkatkan efisiensi dan efektivitas operasinya (Pratama, 2012).

Return saham dipengaruhi oleh beberapa faktor, salah satunya adalah arus kas, dengan melihat angka pada komponen arus Kas, yakni arus kas operasi, arus kas investasi dan arus kas pendanaan, akan membantu investor menganalisis sejauh mana efisiensi perusahaan dalam mengelola kasnya, sehingga investor dapat melihat kemampuan perusahaan untuk membayarkan dividen dari informasi arus kas tersebut (Wehantouw, 2015). Laporan arus kas dapat memberikan informasi yang memungkinkan pengguna untuk mengevaluasi perubahan dalam aset neto entitas, struktur keuangannya (termasuk likiditas dan solvabilitas) dan kemampuannya mempengaruhi jumlah serta waktu arus kas 
dalam rangka penyesuaian terhadap keadaan dan peluang yang berubah. Informasi arus kas dan setara kas memungkinkan pengguna mengembangkan model untuk menilai dan membandingkan nilai kini arus kas masa depan dari berbagai entitas. Informasi tersebut juga meningkatkan daya banding pelaporan kinerja operasi berbagai entitas karena dapat meniadakan pengaruh penggunaan perlakuan akuntansi yang berbeda terhadap transaksi dan peristiwa yang sama. Informasi arus kas historis sering digunakan sebagai indikator dari jumlah, waktu, dan kepastian arus kas masa depan. Di samping itu, arus kas historis juga berguna untuk meneliti kecermatan dari taksiran arus kas masa depan yang telah dibuat sebelumnya dan dalam menentukan hubungan antara profitabilitas dan arus kas neto serta dampak perubahan harga (Wehantouw, 2015).

Selain arus kas, return saham diduga dipengaruhi oleh laba akuntansi. Laba memegang peranan yang sangat penting bagi seluruh perusahaan, dalam bentuk penambahan aktiva atau penurunan kewajiban yang mengakibatkan kenaikan ekuitas yang tidak berasal dari kontribusi penanaman modal selain untuk menilai kinerja laba akuntansi bisa juga digunakan untuk memprediksi kemampuan laba serta menaksir risiko dalam investasi dan kredit (Yocelyn \& Christiawan, 2012). Laba akuntansi didefinisikan sebagai perbedaan antara pendapatan yang direalisasikan yang berasal dari transaksi suatu periode dan berhubungan dengan biaya historis. Dalam metode historical cost laba diukur berdasarkan selisih aktiva bersih awal dan akhir periode yang masing-masing diukur dengan biaya historis sehingga hasil akan sama dengan laba yang dihitung sebagai selisih pendapatan dan biaya (Belkaoui, 2007).

\section{TINJAUAN PUSTAKA}

\section{Return Saham}

Menurut Horne (2012) Return Saham atau yang biasa disebut dengan return merupakan pembayaran yang diterima karena hak kepemilikannya, ditambah dengan perubahan dalam harga pasar yang dibagi dengan harga awal. Brigham (2006) menyatakan bahwa "return atau tingkat pengembalian adalah selisih antara jumlah yang diterima dengan jumlah yang diinvestasikan”. Tandelilin (2010) menyatakan keuntungan merupakan sesuatu yang diharapkan oleh investor dalam berinvestasi. Keuntungan yang di dapat merupakan imbalan atas keberanian investor dalam menanggung risiko.

Menurut Jogiyanto (2014) Return Saham dibedakan menjadi dua yaitu realisasi (realized return) dan ekspektasi (expected return).

a. Return Realisasi. Merupakan return yang sudah terjadi. Return realisasi penting keberadaannya untuk mengukur kinerja perusahaan dan sebagai dasar penentuan return dan risiko dimasa mendatang.

b. Return Ekspektasi. Merupakan return yang diharapkan di masa mendatang dan masih bersifat tidak pasti. Perhitungan return ekspektasi di dasarkan pada return realisasi sebelumnya.

Jogiyanto (2014) mengemukakan beberapa pengukuran return realisasi yang banyak digunakan adalah return total, relative return, kumulatif return, dan return disesuaikan. Ratarata dari return dapat dihitung berdasarkan aritmatika (arithmetic mean) atau rata-rata geometric (geometric mean). Perhitungan ini menggunakan data harga saham histori yaitu pergerakan harga saham dari awal pengamatan sampai akhir pengamatan.Return merupakan hasil yang diperoleh dari suatu investasi. Menurut Jogiyanto (2014) Return Saham dapat dirumuskan sebagai berikut:

$$
\mathrm{Ri}_{t}=\text { Return Saham }=\frac{P t-(P t-i)}{(P t-i)}
$$

Keterangan:

- Rit adalah Return sesungguhnya yang terjadi untuk sekuritas ke-i pada periode peristiwa ke-t

- Pit adalah Harga sekuritas ke-i pada periode peristiwa ke $t$

- Pit-1 adalah Harga sekuritas ke-i pada periode peristiwa sebelumnya 


\section{Laporan Arus Kas}

Arus kas merupakan suatu laporan yang memberikan informasi yang relevan tentang penerimaan dan pengeluaran kas suatu perusahaan pada suatu periode tertentu dengan mengklasifikasikan transaksi pada kegiatan: operasi, pembiayaan dan investasi (Harahap, 2010). Laporan arus kas melaporkan arus kas masuk maupun arus kas keluar suatu perusahaan selama periode tertentu. Laporan arus kas ini akan memberikan informasi mengenai kemampuan perusahaan dalam menghasilkan kas dari aktivitas operasi, melakukan investasi, melunasi kewajiban dan membayar deviden. Laporan arus kas digunakan oleh manajemen untuk mengevaluasi kegiatan operasional yang telah berlangsung, dan merencanakan aktivitas investasi dan pembiayaan di masa yang akan datang. Laporan arus kas juga digunakan oleh kreditur dan investor dalam menilai tingkat likuiditas maupun potensi perusahaan dalam menghasilkan laba (Wehantouw, 2015).

Laporan arus kas adalah Laporan arus kas (statement of cash flow) mengatur persyaratan penyajian pengungkapan laporan arus kas. Informasi tentang arus kas entitas berguna bagi para pengguna laporan keuangan sebagai dasar untuk menilai kemampuan entitas dalam menghasilkan kas dan setara kas serta menilai kebutuhan entitas untuk menggunakan arus kas tersebut (Ikatan Akuntan Indonesia, 2009).

Laporan arus kas dapat diklasifikasikan pada setiap penerimaan dan pengeluaran kedalam kategori aktivitas - aktivitas (Dayanti, 2010):

\section{a. Aktivitas Operasi}

Aktivitas-aktivitas operasi (operating activities) melibatkan produksi dan pengiriman barang untuk dijual serta penyediaan jasa. Arus kas dari aktivitas operasi biasanya menunjukkan dampak dari transaksi yang masuk ke dalam penentuan laba bersih. Yang masuk dalam kategori sebagai arus masuk kas (cash inflows) adalah Penerimaan kas dari pelanggan untuk barang dan jasa yang dibelinya dan Pendapatan bunga dan deviden atas pinjaman dan investasi, dan penjualan surat berharga.
Sedangkan dalam kategori arus keluar kas (cash outflows) adalah pembayaran untuk gaji, barang dan jasa, dan beban operasi. Yang juga dikategorikan sebagai aktivitas operasi adalah penerimaan kas dari setiap surat berharga berbunga atau saham yang dimiliki perusahaan. Selain itu pengeluaran kas untuk pembayaran pajak penghasilan dan pembayaran bunga atas utang perusahaan termasuk dalam klasifikasi aktivitas operasi.

b. Aktivitas Investasi.

Aktivitas-aktivitas investasi (investing activities) biasanya mencakup transaksi- transaksi yang melibatkan:

1) Pemberian pinjaman dan penagihan pokok pinjaman.

2) Perolehan penjualan surat berharga setara kas dan aktiva-aktiva produktif yang diharapkan menghasilkan pendapatan selama beberapa periode.

Arus kas masuk meliputi :

1) Kas yang diterima dari penjualan aktiva tetap.

2) Kas yang diterima penjualan surat berharga dan penagihan pinjaman.

Arus kas keluar meliputi :

1) Kas yang dikeluarkan untuk pembelian aktiva tetap dan surat berharga.

2) Kas yang dipinjamkan ke pihak lain Kenaikan atau penurunan piutang dagang dan persediaan tidak diperlakukan sebagai aktivitas investasi, perubahan aktiva lancar ini dikategorikan sebagai aktivitas operasi.

\section{c. Aktivitas Pendanaan}

Aktivitas Pendanaan adalah Aktivitas yang mengakibatkan perubahan dalam jumlah serta komposisi modal dan pinjaman perusahaan. (PSAK 2011 No.2 Paragraf 05). Aktivitas ini perlu diungkapkan secara terpisah untuk memprediksi klaim terhadap arus kas 
masa depan oleh para pemasok modal perusahaan. Aktivitas - aktivitas pendanaan meliputi 1). Perolehan atau pengembalian sumber daya dari atau kepada pemiliknya dan pemberian imbalan atas investasi mereka dan 2). Perolehan sumber dayadari kreditor dan pembayaran kembali jumlah yang dipinjam atau pelunasan kewajiban.

Arus kas masuk meliputi :

1) Penerbitan wesel, obligasi, hipotik, pinjaman-pinjaman jangka pendek dan jangka panjang.

2) Penerbitan saham biasa dan saham preferen.

Arus kas keluar meliputi :

1) Pelunasan pinjaman.

2) Pembayaran deviden kas.

3) Pembelian saham treasuri.

\section{Laba Akuntansi}

Laba akuntansi biasanya dinyatakan dalam satuan uang. Keberhasilan perusahaan dapat dilihat pada tingkat laba yang diperoleh perusahaan itu sendiri karena tujuan utama perusahaan pada dasarnya adalah untuk memperoleh laba sebesar-besarnya. Laba Akuntansi didefinisikan sebagai perbedaan antara pendapatan yang direalisasikan dari transaksi yang terjadi selama satu periode dengan biaya yang berkaitan dengan pendapatan tersebut (Yocelyn \& Christiawan, 2012).

Laba akuntansi adalah perbedaan antara pendapatan yang direalisasi dari transaksi yang terjadi selama satu periode dengan biaya yang berkaitan dengan pendapatan tersebut (Ghozali, 2016). Menurut Ikatan Akuntan Indonesia (PSAK, 2009), laba Akuntansi adalah laporan utama untuk melaporkan kinerja dari suatu perusahaan selama suatu perioda tertentu. Informasi tentang kinerja perusahaan, terutama tentang profitabilitas,dibutuhkan untuk mengambil keputusan tentang sumber ekonomi yang akan dikelola oleh suatu perusahaan di masa depan.

Laba akuntansi secara operasional didefinisikan sebagai perbedaan antara pendapatan yang direalisasikan yang berasal dari transaksi suatu periode dan berhubungan dengan biaya historis. Dalam metode historical cost laba diukur berdasarkan selisih aktiva bersih awal dan akhir periode yang masingmasing diukur dengan biaya historis sehingga hasil akan sama dengan laba yang dihitung sebagai selisih pendapatan dan biaya (Belkaoui, 2007), sehinggalaba akuntansi dapat diformulakan sebagai berikut :

\section{Laba = Pendapatan - Beban}

\section{METODE PENELITIAN}

\section{Populasi dan Sampel Penelitian}

Penelitian menggunakan sampel perusahaan sub sektor makanan dan minuman yang terdaftar di Bursa Efek Indonesia, dengan melakukan review dan tabulasi data yang bersumber dari laporan keuangan tahun 20152018, sedangkan pemilihan sampel berdasarkan kriteria-kriteria sebagai berikut:

a. Emiten pada perusahaan manufaktur sub sektor makanan dan minuman di Bursa Efek Indonesia yang telah terdaftar di BEI sejak tahun 2015 sampai tahun 2018.

b. Tersedia data laporan keuangan tahunan yang berakhir 31 desember untuk periode 2015 sampai dengan Desember periode 2018 serta memiliki kelengkapan dalam laporan keuangan sesuai dengan data yang diperlukan dalam variabel penelitian.

c. Laporan keuangan yang disajikan dalam bentuk mata uang Rupiah.

d. Perusahaan Emiten pada perusahaan manufaktur sub sektor makanan dan minuman di Bursa Efek Indonesia yang sebelum tahun 2015 sudah go public.

e. Tidak melakukan stock split selama kurun waktu pengamatan.

Berdasarkan kriteria, maka sampel emiten dalam penelitian ini sebagai berikut:

Tabel 1. Emiten Sampel Penelitian

\begin{tabular}{|l|l|}
\hline No & Nama Perusahaan \\
\hline 1 & $\begin{array}{l}\text { ADES (Akasha Wira International } \\
\text { Tbk) }\end{array}$ \\
\hline 2 & ULTJ (Ultrajaya Milk Industry and \\
\hline
\end{tabular}




\begin{tabular}{|l|l|}
\hline No & Nama Perusahaan \\
\hline 3 & Tranding Company Tbk) \\
\hline 4 SKBM (Sekar Bumi Tbk) \\
\hline 5 & ALTO (Tri Banyan Tirta Tbk) \\
\hline 6 & $\begin{array}{l}\text { ICBKA (Cahaya Kalbar Tbk) (Indofood CBP Sukses } \\
\text { Makmur Tbk) }\end{array}$ \\
\hline 7 & $\begin{array}{l}\text { INDF (Indofood Sukses Makmr } \\
\text { Tbk) }\end{array}$ \\
\hline 8 & $\begin{array}{l}\text { MLBI (Multi Bintang Indonesia } \\
\text { Tbk) }\end{array}$ \\
\hline 9 & $\begin{array}{l}\text { PSDN (Prasidha Aneka Niaga } \\
\text { Tbk) }\end{array}$ \\
\hline 10 & $\begin{array}{l}\text { ROTI (Nippon Indosari } \\
\text { Corporindo Tbk) }\end{array}$ \\
\hline 11 & SKLT (Sekar Laut Tbk) \\
\hline 12 & STTP (Siantar Top Tbk) \\
\hline
\end{tabular}

Sumber : Bursa Efek Indonesia, 2020.

\section{Metode Analisis Data}

\section{Analisis Deskriptif}

Analisis secara deskriptif bermaksud untuk menjabarkan data yang diperoleh dari hasil pengumpulan data, diantaranya dengan mengetahui nilai rata-rata, modus, median dan lainnya.

\section{Uji Asumsi Klasik}

Beberapa asumsi yang harus dipenuhi terlebih dahulu sebelum menggunakan Multiple Linear Regression sebagai alat untuk menganalisis pengaruh variabel-variabel yang diteliti. Pengujian asumsi klasik yang digunakan terdiri atas uji normalitas, multikolinieritas, dan uji autokorelasi

\section{Analisis Regresi Berganda}

Metode pengolahan data yang digunakan penelitian ini adalah regresi berganda dengan bantuan software SPSS 23. Metode regresi berganda yaitu metode statistik untuk menguji pengaruh antara beberapa variabel bebas terhadap satu variabel terikat. Adapun model yang terbentuk dalam penelitian ini adalah:

$$
Y=\alpha+\beta_{1} x_{1}+\beta_{2} X_{2}+\beta_{3} X_{3}+\beta_{4} X_{4} \varepsilon
$$

Dimana:

$$
\begin{array}{ll}
\mathrm{Y} & =\text { Return Saham } \\
\alpha & =\text { Intercept } \text { atau konstanta }
\end{array}
$$

$$
\begin{array}{ll}
\beta_{1}, \beta_{2}, \beta_{3}, \beta_{4} \quad=\text { Koefisien regresi } \\
X_{1} \quad=\text { Arus kas operasi } \\
X_{2} \quad=\text { Arus kas investasi } \\
X_{3} \quad=\text { Arus kas pendanaan } \\
X_{4} \quad=\text { Laba akuntansi } \\
\varepsilon & =\text { Error term }
\end{array}
$$

\section{HASIL PENELITIAN}

\section{Statistik Deskriptif}

Statistik deskriptif yang disajikan dari hasil penelitian ini bertujuan memberikan gambaran secara umum mengenai penyebaran data yang diperoleh dilapangan. Hasil pengolahan data statistik deskriptif dapat dilihat pada tabel berikut:

\section{Tabel 2. Statistik Deskriptif Return Saham}

\section{Statistics}

Return Saham

\begin{tabular}{|l|l|}
\hline $\mathrm{N} \quad$ Valid & 48 \\
Mean $\quad$ Missing & 0 \\
Std. Error of Mean &,- 0622 \\
Median &, 06845 \\
Mode &, 0290 \\
Std. Deviation & $-2,53^{\mathrm{a}}$ \\
Variance &, 47425 \\
Skewness &, 225 \\
Std. Error of Skewness & $-3,290$ \\
Kurtosis &, 343 \\
Std. Error of Kurtosis & 15,735 \\
Range &, 674 \\
Minimum & 3,25 \\
Maximum & $-2,53$ \\
Sum &, 72 \\
\hline
\end{tabular}

Sumber : Data diolah, 2020.

Berdasarkan hasil pengolahan data pada Tabel 2, data return saham yang diperoleh mempunyai rata-rata $-0,0622$, median sebesar 0,029 , nilai minimum $-2,53$ dan Nilai maksimum 0,72 .

Tabel 3. Statistik Deskriptif Arus Kas Operasi

\section{Statistics}

Arus Kas Operasi 


\begin{tabular}{|l|l|}
\hline $\mathrm{N} \quad$ Malid & 48 \\
Mean $\quad$ Missing & 0 \\
Std. Error of Mean & 1114,113 \\
Median & 281,4691 \\
Mode & 201,850 \\
Std. Deviation & $-98,7^{\mathrm{a}}$ \\
Variance & 1950,0753 \\
Skewness & 3802793,861 \\
Std. Error of Skewness & 1,957 \\
Kurtosis &, 343 \\
Std. Error of Kurtosis & 2,600 \\
Range &, 674 \\
Minimum & 7274,3 \\
Maximum & $-98,7$ \\
Sum & 7175,6 \\
\hline
\end{tabular}

Sumber : Data diolah, 2020.

Berdasarkan hasil pengolahan data pada Tabel 3, data arus kas operasi yang diperoleh mempunyai rata-rata $1.114,113$ (milyar), median sebesar 201,85 (milyar), nilai minimum -98,7 (milyar) dan nilai maksimum 53.477,4 (miyar).

\section{Tabel 4. Statistik Deskriptif Arus Kas InvestasiStatistics}

Arus Kas Investasi

\begin{tabular}{|l|l|}
\hline N $\quad$ Malid & 48 \\
Mean & 0 \\
Std. Error of Mean & $-861,835$ \\
Median & 297,7350 \\
Mode & $-157,650$ \\
Std. Deviation & $-11223,7^{\mathrm{a}}$ \\
Variance & 2062,7687 \\
Skewness & 4255014,61 \\
Std. Error of & $-3,580$ \\
Skewness &, 343 \\
Kurtosis & 14,216 \\
Std. Error & of \\
Kurtosis &, 674 \\
Range & 11444,3 \\
Minimum & $-11223,7$ \\
Maximum & 220,6 \\
Sum & $-41368,1$ \\
\hline
\end{tabular}

Sumber : Data diolah, 2020.
Berdasarkan hasil pengolahan data pada Tabel 4, data arus kas investasi yang diperoleh mempunyai rata-rata $-861,835$ (milyar), median sebesar $-157,650$ (milyar), nilai minimum $-11.223,7$ (milyar) dan nilai maksimum 220,6 (miyar).

Tabel 5. Statistik Deskriptif Arus Kas Pendanaan

\section{Statistics}

Arus Kas Pendanaan

\begin{tabular}{|l|l|}
\hline $\mathrm{N} \quad$ Valid & 48 \\
Mean $\quad$ Missing & 0 \\
Std. Error of Mean & $-366,385$ \\
Median & 165,0844 \\
Mode & $-18,400$ \\
Std. Deviation & $-5807,9^{\mathrm{a}}$ \\
Variance & 1143,7381 \\
Skewness & 1308136,872 \\
Std. Error of Skewness & $-3,294$ \\
Kurtosis &, 343 \\
Std. Error of Kurtosis & 12,739 \\
Range &, 674 \\
Minimum & 7089,9 \\
Maximum & $-5807,9$ \\
Sum & 1282,0 \\
\hline
\end{tabular}

Sumber : Data diolah, 2020.

Berdasarkan hasil pengolahan data pada Tabel 5 , data arus kas pendanaan yang diperoleh mempunyai rata-rata $-366,385$ (milyar), median sebesar -18,4 (milyar), nilai minimum 5.807,9 (milyar) dan nilai maksimum 1.282 (miyar).

Tabel 6. Statistik Deskriptif Laba Akuntansi Statistics

Laba Akuntansi

\begin{tabular}{|l|l|}
\hline $\mathrm{N} \quad$ Malid & 48 \\
Mean $\quad$ Missing & 0 \\
Std. Error of Mean & 952,254 \\
Median & 248,1434 \\
Mode & 152,750 \\
Std. Deviation & $-62,8^{\mathrm{a}}$ \\
Variance & 1719,1882 \\
Skewness & 2955608,129 \\
Std. Error of Skewness & 1,961 \\
Kurtosis &, 343 \\
& 2,547
\end{tabular}




\begin{tabular}{|l|l|} 
Std. Error of Kurtosis &, 674 \\
Range & 6413,6 \\
Minimum & $-62,8$ \\
Maximum & 6350,8 \\
Sum & 45708,2 \\
\hline
\end{tabular}

Sumber : Data diolah, 2020.

Berdasarkan hasil pengolahan data pada Tabel 6, data laba akuntansi yang diperoleh mempunyai rata-rata 952,254 (milyar), median sebesar 152,750 (milyar), nilai minimum -62,8 (milyar) dan nilai maksimum 6.350,8 (miyar).

\section{Uji Asumsi Klasik}

Hasil uji asumsi klasik dapat dilihat pada tabeltabel berikut.

\section{Tabel 7. Uji Normalitas}

\begin{tabular}{|c|c|c|c|c|c|c|}
\hline \multicolumn{7}{|c|}{ One-Sample Kolmogorov-Smirnov Test } \\
\hline & & $\begin{array}{l}\text { Arus Kas } \\
\text { Operasi }\end{array}$ & $\begin{array}{l}\text { Arus Kas } \\
\text { Investasi }\end{array}$ & $\begin{array}{l}\text { Arus Kas } \\
\text { Pendanaan }\end{array}$ & $\begin{array}{c}\text { Laba } \\
\text { Akuntansi }\end{array}$ & $\begin{array}{l}\text { Return } \\
\text { Saham }\end{array}$ \\
\hline \multicolumn{2}{|l|}{$\mathrm{N}$} & & & & 48 & 48 \\
\hline \multirow{2}{*}{$\mid \begin{array}{l}\text { Normal } \\
\text { Parameters }\end{array}$} & Mean & 1114,112 & $-861,835$ & $-366,385$ & 952,254 & 17,85 \\
\hline & $\begin{array}{l}\text { Std. } \\
\text { Devia }\end{array}$ & 1950,0753 & 2062,7687 & 1143,7381 & 1719,1882 & 1368,272 \\
\hline 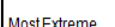 & Absolute &, 299 & .401 & ,321 &, 329 & 266 \\
\hline Differences & Positi & 299 &, 316 & 255 & .329 & 203 \\
\hline \multirow{2}{*}{\multicolumn{2}{|c|}{\begin{tabular}{|l} 
Kolmogorov-SmirnovZ \\
Asymp. Sig. (2-tailed)
\end{tabular}}} & 2,068 & 2,779 & 2,222 & 2,277 &,- 2664 \\
\hline & & .081 & .062 & .105 &, 072 & 212 \\
\hline
\end{tabular}

Sumber : Data diolah, 2020.

Pada tabel 7. terlihat bahwa nilai KolmogorovSmirnov untuk semua sampel lebih besar dari 0,05, sehingga $\mathrm{H}_{0}$ diterima, dengan kata lain bahwa data dari semua sampel pada penelitian ini berdistribusi normal.

\section{Tabel 8. Uji Multikolinieritas}

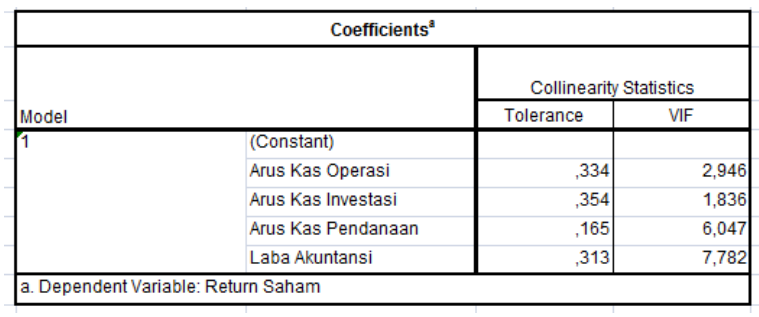

Sumber : Data diolah, 2020.

Dari tabel 8 terlihat semua variabel bebas, memiliki nilai VIF lebih kecil dari 10, sehingga dapat disimpulkan tidak terjadi adanya penyimpangan asumsi klasik multikolinieritas antar variabel bebas dalam model.
Tabel 9. Uji Autokorelasi

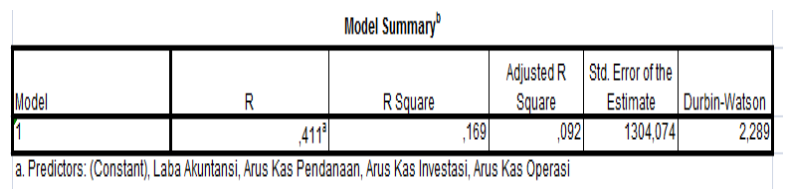

Sumber : Data diolah, 2020.

Dari hasil pengujian data, penelitian memiliki nilai $\mathrm{DW}=2,289$, yang berada sekitar 2 , sehingga data terbebas dari masalah autokorelasi.

\section{Analisis Regresi Berganda}

Berikut hasil uji regresi berganda pengaruh arus kas operasi, arus kas investasi, arus kas pendanaan dan laba akuntansi terhadap return saham.

\section{Tabel 9. Koefisien Regresi}

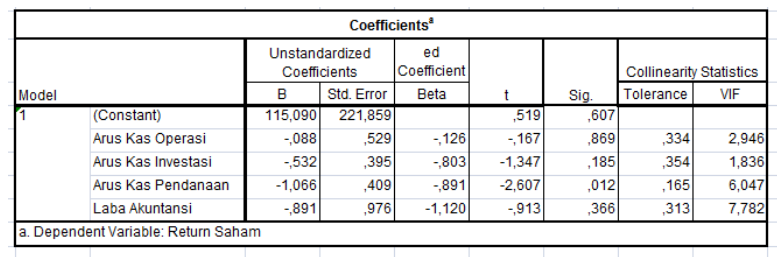

Sumber : Data diolah, 2020.

Dari hasil olah data diperoleh persamaan regresi berganda sebagai berikut:

\section{$\widehat{\mathbf{Y}}=115,09-0,088 X_{1}-0,532 X_{2}-1,06 X_{3}-$ $0,89 \mathrm{X}_{3}$ e}

Berdasarkan persamaan regresi yang diperoleh, maka model regresi tersebut dapat diinterpretasikan sebagai berikut:

a. Koefisien konstanta sebesar 115,09 menunjukkan bahwa apabila nilai X1, X2 dan X3 bernilai nol maka return saham sebesar 115,09 satuan.

b. Koefisien $b_{1}, b_{2}, b_{3}, b_{4}$ menunjukkan tanda negatif. Berdasarkan nilai pada uji t, hanya variabel arus kas pendanaan yang memiliki nilai signifikansi dibawah $0,05(0,012<0,05)$, sehingga dapat disimpulkan hanya variabel arus kas pendanaan yang berpengaruh signifikan terhadap return saham, sedangkan variabel arus kas operasi, arus kas investasi dan laba akuntansi tidak berpengaruh terhadap return saham. 


\section{Tabel 10. Uji Signifikansi}

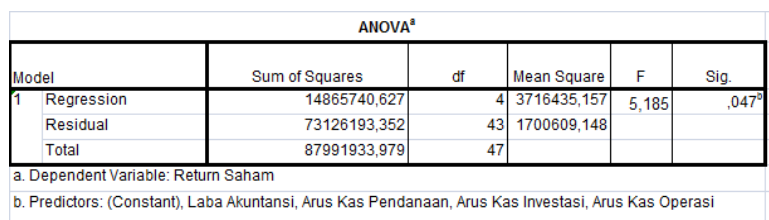

Sumber : Data diolah, 2020.

Dari pengolahan data pada Tabel 10 terlihat bahwa nilai $F_{\text {hitung }}=5,185$, sedangkan nilai $\mathrm{F}_{\text {tabel }}=2,58$ sehingga disimpulkan $\mathrm{F}_{\text {hitung }}>\mathrm{F}_{\text {tabel }}$ $(5,185>2,58)$. Begitupula nilai Sig $\mathrm{F}=0.047$, lebih kecil dari 0,05 , maka kesimpulannya $\mathrm{H}_{0}$ ditolak yang berarti bahwa koefisien regresi secara simultan signifikan, dengan kata lain bahwa terdapat pengaruh yang signifikan variabel bebas arus kas operasi, arus kas investasi, arus kas pendanaan dan laba akuntansi secara bersama-sama terhadap variabel terikat return saham.

Tabel 11. Koefisien Korelasi

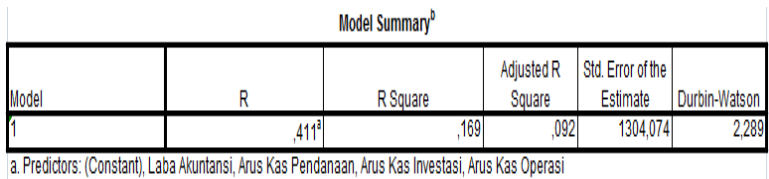

Sumber : Data diolah, 2020.

Koefisien korelasi (r) adalah 0,411, hal ini berarti ada hubungan yang positif antara variabel bebas arus kas operasi, arus kas investasi, arus kas pendanaan dan laba akuntansi dengan variabel terikat return saham, dan hubungannya adalah cukup kuat, sebab berada pada selang korelasi 0,400 - 0,599. Adapun besaran pengaruh persamaaan model memiliki Koefisien determinasi sebesar 0,169 menunjukkan bahwa besarnya kontribusi arus kas operasi, arus kas investasi, arus kas pendanaan dan laba akuntansi dengan return saham sebesar $16,9 \%$, sisanya disebabkan oleh faktor lain.

\section{Pembahasan Hasil Penelitian}

Hasil penelitian ini sesuai dengan hasil penelitian (Kristanto, 2015), (Pratama, 2012), (Purwanti \& W, 2015), (Suryani, Yuliarti, A., \& Diyani, 2017) yang menunjukkan komponen arus kas, yakni arus kas operasi, arus kas investasi dan arus kas pendanaan tidak selalu memiliki pengaruh signifikan terhadap return saham. Hal ini juga menandakan bahwa investor tidak terpengaruh oleh besaran arus kas yang dimiliki perusahaan. Kristanto (2015) menyatakan peningkatan arus kas operasi yang menjadi pertanda bahwa perusahaan memiliki kemampuan yang cukup untuk melunasi pinjaman, memelihara kemampuan perusahaan untuk tetap beroperasi, membayar dividen dan melakukan investasi untuk operasi baru juga tidak dilihat oleh investor dalam mengambil keputusan investasinya.

Hasil penelitian Pratama (2012) menyimpulkan investor tidak melihat pelaporan perubahan arus kas operasi sebagai informasi yang dapat mengambil keputusan investasinya. Pada arus kas investasi yang menyangkut perolehan atau pelepasan aktiva jangka panjang serta investasi lain yang tidak termasuk dalam setara kas, mencakup aktivitas meminjamkan uang dan mengumpulkan piutang tersebut serta memperoleh dan menjual investasi dan aktiva jangka panjang produktif, menunjukan arus kas investasi tidak dapat dijadikan alat ukur besarnya return saham karena para investor kurang menanggapi informasi yang diberikan oleh arus kas investasi dan para investor BEI masih berorientasi jangka pendek dalam berinvestasi di BEI atau untuk spekulasi, dan bukan investor yang berorientasi jangka panjang yang menginvestorkan aspek tekhnikal perusahaan. Sedangkan pada arus pendanaan, dimana berisi tentang informasi-informasi yang mengakibatkan perubahan dalam jumlah serta komposisi ekuitas dan hutang jangka panjang perusahaan. Investor dalam hal ini sudah melihat pelaporan transaksi yang merubah ekuitas dan hutang jangka panjang serta pembayaran dividen tunai sebagai informasi yang dapat digunakan untuk pengambilan keputusan investasinya. Hal ini ditunjukkan dengan nilai signifikan pada pengaruh arus pendanaan terhadap return saham.

Begitupula pada laba akuntansi, temuan penelitian yang menunjukkan bahwa laba akuntansi tidak berpengaruh signifikan terhadap return saham mengindikasikan bahwa para investor cenderung tidak bergerak karena informasi laba akuntansi, sehingga dapat disimpulkan laba akuntansi kurang dipercaya untuk mengambil keputusan dalam investasi saham oleh investor. Hasil dari 
penemuan ini seusai dengan penelitian yang telah dilakukan oleh Kristanto (2015) yang menyatakan hal ini terjadi karena pihak manajemen dimungkinkan untuk menekan pihak akuntan untuk melakukan pencatatan dengan metode yang memaksimalkan laba ataupun melakukan income smoothing, sehingga investor masih kurang mempercayai laporan laba akuntansi yang ada dalam laporan keuangan.

\section{SIMPULAN}

Berdasarkan hasil penelitian, maka kesimpulan penelitian ini adalah pertama, Berdasarkan hasil uji regresi secara parsial hanya variabel arus kas pendanaan yang berpengaruh signifikan terhadap return saham, sedangkan variabel arus kas operasi, arus kas investasi dan laba akuntansi tidak berpengaruh terhadap return saham. Kedua, Berdasarkan hasil uji regresi secara simultan, terdapat pengaruh yang signifikan variabel bebas arus kas operasi, arus kas investasi, arus kas pendanaan dan laba akuntansi secara bersama-sama terhadap variabel terikat return saham. Ketiga, Ada hubungan yang positif antara variabel bebas arus kas operasi, arus kas investasi, arus kas pendanaan dan laba akuntansi dengan variabel terikat return saham, dan hubungannya adalah cukup kuat. Keempat, besaran pengaruh persamaaan model memiliki Koefisien determinasi sebesar 0,169 menunjukkan bahwa besarnya kontribusi arus kas operasi, arus kas investasi, arus kas pendanaan dan laba akuntansi dengan return saham sebesar 16,9\%, sisanya disebabkan oleh faktor lain.

\section{SARAN}

Berdasarkan hasil penelitian, maka saran yang dapat diberikan adalah pertama, Hasil penelitian menunjukkan secara parsial, variabel arus kas operasi, arus kas investasi dan laba akuntansi tidak berpengaruh terhadap return saham, artinya investor tidak melihat pelaporan perubahan arus kas dan laba akuntansi dalam pengambilan keputusan investasinya, padahal angka pada laporan arus kas dan laba adalah angka penting yang perlu dianalisi, oleh karena itu, disarankan kepada investor sebaiknya cermat memilih perusahaan yang dapat terus beroperasi walaupun kondisi ekonomi sedang menurun, yakni dengan memperhatikan nilai atau angka pada arus kas dan laba akuntansi. Kedua, Penelitian selanjutnya diharapkan dapat memasukkan variabel lain yang belum termasuk dalam penelitian ini.

\section{DAFTAR PUSTAKA}

Belkaoui. (2007). Teori Akuntansi (Pertama). Jakarta: Salemba Empat.

Brigham, E. dan J. F. H. (2006). Dasar-dasar Manajemen Keuangan (Sepuluh). Jakarta: Salemba Empat.

Dayanti, E. (2010). Pengaruh laporan arus kas dan likuiditas perusahaan terhadap return saham pada perusahaan yang terdaftar di BEI. Jurusan Akuntansi UIN Jakarta.

Fahmi. (2011). Analisis Laporan Keuangan (Pertama). Bandung: Alfabeta.

Ghozali, I. dan C. (2016). Teori Akuntansi. Semarang: Universitas Diponegoro.

Harahap, S. S. (2010). Analisis Kritis Atas Laporan Keuangan. Jakarta: Rajawali Press.

Horne, J. C. V. \& J. W. (2012). Prinsip ᄀprinsip Manajemen Keuangan. Jakarta: Salemba Empat.

Ikatan Akuntan Indonesia. (2009). Standar Akuntansi Keuangan. Jakarta: Salemba Empat.

Jogiyanto, H. (2014). Teori Portofolio dan Analisis Investasi (Sembilan). Yogyakarta: BPFE Yogyakarta.

Kristanto, H. dan S. (2015). Pengaruh Perubahan Arus Kas Operasi, Laba Akuntansi, Suku Bunga, Dan Inflasi Terhadap Return Saham Haris Kristanto dan Sumani Universitas Katolik Atma Jaya. 4(2), 522-539.

Pradhono \& Christiawan, Y. J. (2004). Pengaruh Economic Value Added, Operasi Terhadap Return Yang Diterima Oleh Pemegang Saham ( Studi pada perusahaan manufaktur yang terdaftar di Bursa Efek Jakarta ). Jurusan Akuntansi Universitas Petra Surabaya, 140-165. 
Pratama, S. (2012). Pengaruh Laba Akuntansi Dan Komponen Arus Kas Terhadap Return Saham Pada Perusahaan Manufaktur Yang Terdaftar Di Bursa Efek Indonesia. STIE MDP, 1-9.

Purwanti, S., \& W, E. M. (2015). Pengaruh Laba Akuntansi Dan Arus Kas Terhadap Return Saham Perusahaan Yang Listing Di BEI. 16(01), 113-123.

Suryani, Yuliarti, A., \& Diyani, L. A. (2017). ). Pengaruh Laba Akuntansi Dan Arus Kas Terhadap Return Sahamm Pada Perusahaan Otomotif. The Indonesian Accounting Review.

Tandelilin, E. (2010). Portofolio dan Investasi: Teori dan aplikasi. Jakarta: Kanisius.

Wehantouw, A. B. \& J. J. T. (2015). Analisis laporan arus kas operasi, investasi dan pendanaan pada pt. gudang garam tbk. Jurnal EMBA, 3(1), 806-817.

Yocelyn, A., \& Christiawan, Y. J. (2012). Analisis Pengaruh Perubahan Arus Kas dan Laba Akuntansi Terhadap Return Saham pada Perusahaan Berkapitalisasi Besar. Jurnal Akuntansi Dan Keuangan, 14(2), 81-90. 